\title{
Electron Microscopic Studies of Chlorella ellipsoidea Protoplast Formation
}

\author{
By TAKASHI YAMADA* AND KENJI SAKAGUCHI \\ Mitsubishi-Kasei Institute of Life Sciences, 11 Minamiooya, Machida-shi, Tokyo 194, Japan
}

(Received 26 August 1981; revised 9 November 1981)

\begin{abstract}
The intermediate stages of protoplast formation of Chlorella ellipsoidea were studied by transmission and scanning electron microscopy. Within the first few hours of treatment with a polysaccharide-degrading enzyme mixture, the microfibrillar inner component of the cell wall was almost completely digested and the remaining outermost component was released irregularly from the plasma membrane. As incubation proceeded, a crevice which occurred at a fold of the outer wavy layer gradually extended through the layer; then, the surface of the plasma membrane was exposed from the crevice. The gradually degrading outer layer peeled off and an almost spherical protoplast with fine furrows on its surface was released.

Degradation of the outermost thin layer of cell wall, probably composed of pectin, limits the rate of protoplast formation in C. ellipsoidea.
\end{abstract}

\section{INTRODUCTION}

The existence of a rigid and indigestible cell wall has restricted some studies on Chlorella. The resistance of cell wall against enzyme attack is not solely due to the sporopollenin layer in the cell wall (Atkinson et al., 1972). Even strains without sporopollenin in their cell wall vary in the morphology and composition of their cell walls (Soeder, 1964) and possess very heterogeneous cell wall components (Takeda \& Hirokawa, 1978); the relationship between stability and morphology or composition of the cell wall has not been clarified.

Recently, we treated twelve strains of Chlorella which lack the sporopollenin layer in their cell wall with some polysaccharide-degrading enzyme mixtures and found that two strains (Chlorella ellipsoidea C-87 and Chlorella saccharophila C-211) can be easily induced to form protoplasts (Yamada \& Sakaguchi, 1981). The protoplastic nature was verified by osmotic lability, spherical shape, sticky surface nature, Calcofluor staining, and electron microscopy. Protoplasts of $C$. ellipsoidea $\mathrm{C}-87$ were shown to be able to regenerate the cell wall and to grow on a regeneration medium.

In this study, we characterize ultrastructural changes during the protoplast formation of $C$. ellipsoidea, using transmission and scanning electron microscopy, in order to elucidate the reason why the strain can be induced to form protoplasts and to reveal the relationship between stability and structure of the cell wall.

\section{METHODS}

Experimental cultures. Chlorella ellipsoidea Gerneck (IAM C-87) was obtained from the algal culture collection of the Institute of Applied Microbiology, University of Tokyo. The cells were cultured in a modified Bristol medium (Watanabe, 1960) supplemented with $0.1 \%(\mathrm{w} / \mathrm{v})$ proteose peptone. The cells were grown in flasks on a reciprocal shaker with a $16 \mathrm{~h}$ light $(3000 \mathrm{~lx}) / 8 \mathrm{~h}$ dark cycle for $4-5 \mathrm{~d}$.

Preparation of protoplasts. Protoplasts were prepared from freshly harvested cells as previously described (Yamada \& Sakaguchi, 1981): the cell suspension $\left(2 \times 10^{8}\right.$ cells $\left.\mathrm{ml}^{-1}\right)$ in $25 \mathrm{~mm}$-phosphate buffer $(\mathrm{pH} \mathrm{6.0)}$ containing $0.6 \mathrm{M}$-sorbitol/mannitol $(1: 1), 4 \%(\mathrm{w} / \mathrm{v})$ cellulase Onozuka R-10 (Kinki Yakult MFG, Japan), 2\% 
(w/v) Macerozyme R-10 (Kinki Yakult MFG, Japan), and 1\% (w/v) pectinase (Aspergillus niger; Sigma) was incubated at $25^{\circ} \mathrm{C}$ in a shaker water bath with gentle shaking. The formation of osmotically sensitive structures was monitored by adding $0.1 \mathrm{ml}$ of the suspension to $2.9 \mathrm{ml}$ of water and by counting disrupted cells by a haemocytometer.

Electron microscopy. Portions of the suspension of cells in the enzyme mixture were removed at intervals and centrifuged at $1000 \mathrm{~g}$ at $4^{\circ} \mathrm{C}$. After washing twice with $25 \mathrm{~mm}$-phosphate buffer that contained $0.6 \mathrm{M}$ sorbitol/mannitol, cells were fixed with $3 \%(\mathrm{w} / \mathrm{v})$ glutaraldehyde in the same buffer for $2 \mathrm{~h}$ at room temperature and post-fixed with $1 \%(\mathrm{w} / \mathrm{v}) \mathrm{OsO}_{4}$ in the same buffer for $1 \mathrm{~h}$ at $4{ }^{\circ} \mathrm{C}$. For scanning electron microscopy, the fixed cells were dehydrated in a graded ethanol series, suspended in acetone, and dried in a Hitachi HCP-I critical-point dryer. A small portion of the dried cells was attached to a conductive stub and sputter-coated with gold in a Eiko JB-3 ion coater. Samples were examined by a JEM-100CX (JEOL) scanning electron microscope.

For transmission electron microscopy, the fixed cells were embedded in $2 \%(\mathrm{w} / \mathrm{v})$ agar, dehydrated as above, transferred to QY-1 ( $n$-butylglycidyl ether), and immersed in Epon (Millonig \& Marinozzi, 1968). Thin sections were cut by a Sorval MT-1 microtome, and stained with $2 \%(\mathrm{w} / \mathrm{v})$ uranyl acetate for 30 min followed by a lead salts mixture (Millonig, 1963) for $5 \mathrm{~min}$. They were examined by a JEM-100B (JEOL) electron microscope.

Staining procedures. $\beta$-Linked polysaccharides in the cell wall were stained with Calcofluor white ST (Maeda \& Ishida, 1967) by the method of Nagata \& Takebe (1970). Pectin was stained with Ruthenium red (Sigma) according to Soeder (1963).

\section{RESULTS}

The vegetative cells of $C$. ellipsoidea $\mathrm{C}-87$ are ellipsoids of $3-3.5 \mu \mathrm{m} \times 4 \mu \mathrm{m}$ (Fig. 1 a) and are surrounded by a cell wall which consists of two regions (Fig. $1 b$ ): an outer thin layer $(10 \mathrm{~nm}$ in width) and an inner bulky microfibrillar layer (width from $100 \mathrm{~nm}$ to $200 \mathrm{~nm}$ ). The former layer of cell wall showed higher affinity to the staining with uranyl acetate and lead salts than the latter. No trilaminar outer component of sporopollenin (Atkinson et al., 1972) was observed at any stage of the cell cycle. Whole cells and cell wall fragments showed an intense light blue fluorescence when stained with Calcofluor white ST and were positive in the Ruthenium red stain. Scanning electron micrographs of the vegetative cells suspended in a hypertonic medium $(0.6 \mathrm{M}$-sorbitol/mannitol, $\mathrm{pH} 6.0)$ showed that the surface of cell wall was roughly folded and veinlike furrows extended over the wall (arrows in Fig. 2a). This was used as a structural marker to distinguish whole cells from protoplasts. When the cells were incubated for $2-3 \mathrm{~h}$ in the protoplast-forming medium (about $30 \%$ of the cells were osmotically labile: Yamada \& Sakaguchi, 1981), small breaks occurred at or beside a fold on the surface of the cell wall (arrow in Fig. $3 a$ ). Thin sections of the cells at this stage showed that the inner region of the cell wall had almost disappeared and that the outer region had been irregularly released apart from the plasma membrane (Fig. $3 b$ ). After staining with Calcofluor white ST, the cells at this stage showed only very faint or no blue fluorescence (Fig. 4). Figures $5(a)$ and $5(b)$ show scanning electron micrographs of cells incubated for $4-5 \mathrm{~h}$ (about $50 \%$ of the cells were osmotically labile). Most vegetative cells had large breaks on the outer layer of the cell wall and through them, the rugose surface of the plasma membrane was exposed (arrows in Figs $5 a$ and $b$ ). Figure $5(c)$ shows a thin section of the cell at this stage; the outer region of the cell wall is considerably degraded (arrows). After this stage the remaining portions of the cell wall occasionally came off and almost spherical protoplasts appeared into the medium (Fig. $6 a$ ); the empty wall structure was visible beside the protoplast (Fig. $6 a, b$ ). After 6-8 $\mathrm{h}$ incubation, most of the cell population had converted to protoplasts (Fig. 7). Figure $8(a)$ shows a scanning electron micrograph of a typical protoplast, which is spherical, $4.5 \mu \mathrm{m}$ in diameter, with a somewhat rugose surface, and without any fragments of the cell wall. The protoplastic nature was confirmed by a thin section (Fig. $8 b$ ); the plasma membrane was wavy and without any fragments of the cell wall.

Some of the protoplasts, suspended in culture medium containing $20 \%(\mathrm{w} / \mathrm{v})$ sucrose, could, after 3-4 d incubation at $25^{\circ} \mathrm{C}$ in the light (3000 lx), regenerate the cell wall, which was stained with Calcofluor (Fig. 9). When the protoplasts were embedded in $0.6 \%$ soft agar culture medium containing $20 \%$ sucrose and $0.1 \%$ yeast extract (Difco), up to $30 \%$ of the 


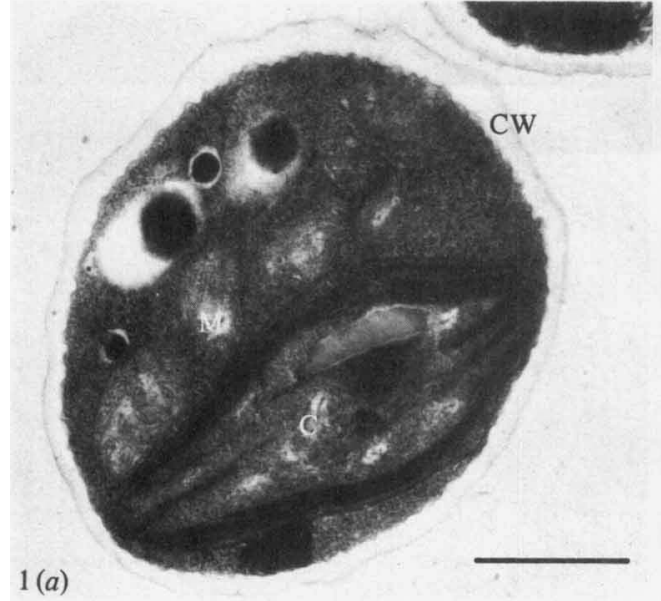

$1(a)$

Fig. 1. Electron micrographs showing an intact vegetative cell of $C$. ellipsoidea. (a) Thin section of a whole cell; $(b)$ thin section of the cell wall: $\mathrm{C}$, chloroplast; $\mathrm{CW}$, cell wall; $\mathrm{I}$, inner region of cell wall; $\mathrm{M}$, mitochondrion; $\mathrm{O}$, outer region of cell wall; $\mathrm{P}$, plasma membrane; $\mathrm{T}$, thylakoid. The bar marker represents $1 \mu \mathrm{m}$ in $(a)$ and $0.2 \mu \mathrm{m}$ in $(b)$.

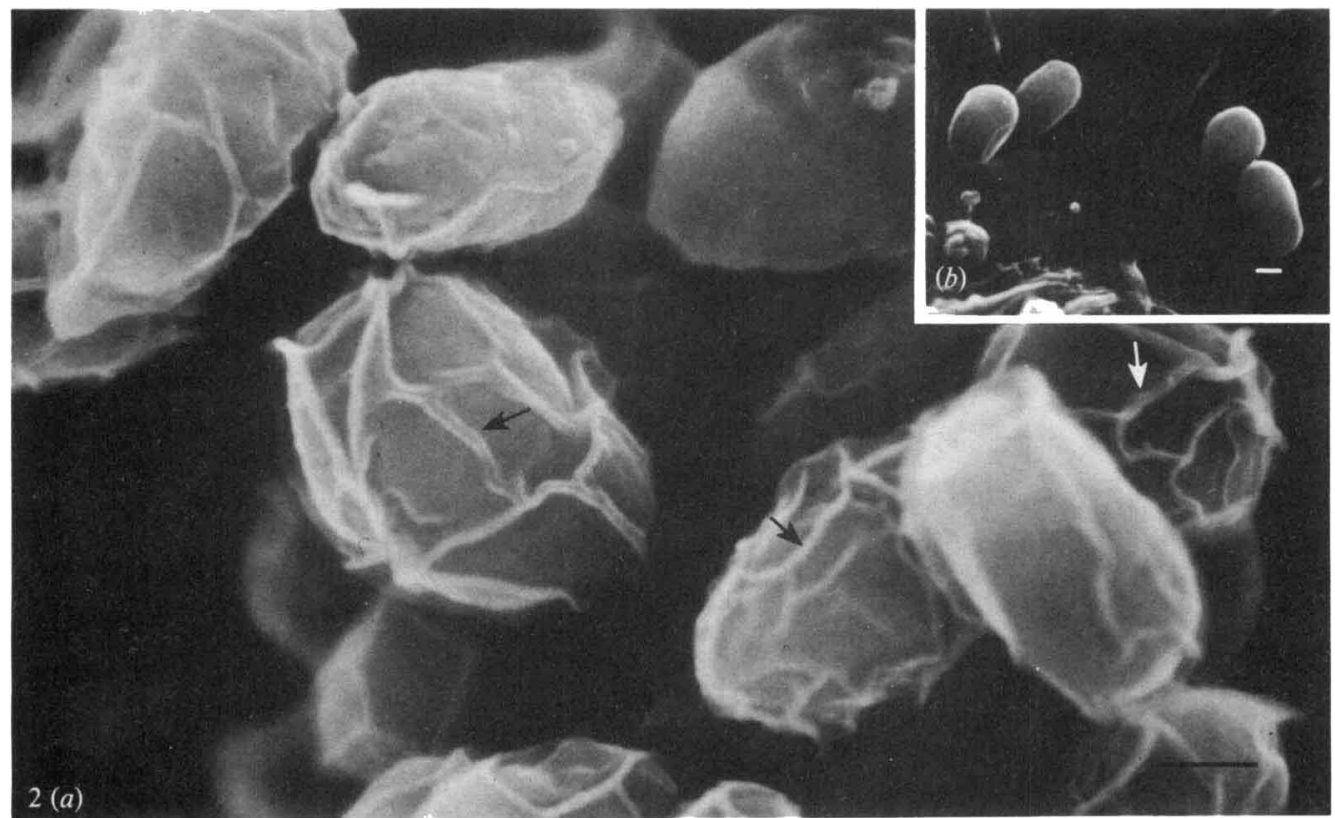

Fig. 2. Scanning electron micrograph of $C$. ellipsoidea cells. (a) Cells suspended in $0.6 \mathrm{M}-$ sorbitol/mannitol $(1: 1)$ at $\mathrm{pH} 6 \cdot 0$. The arrows indicate furrows on the surface of the cell wall. $(b)$ Cells in the growth medium. The surface of the cell wall is smooth. The bar markers represent $1 \mu \mathrm{m}$.

protoplasts could grow and form colonies on the plates after 2 weeks incubation at $25^{\circ} \mathrm{C}$ in the light.

\section{DIS CUSSION}

The process of protoplast formation reported here is somewhat different from that for $C$. saccharophila reported by Braun \& Aach (1975) and that for C. vulgaris by Berliner (1977). 

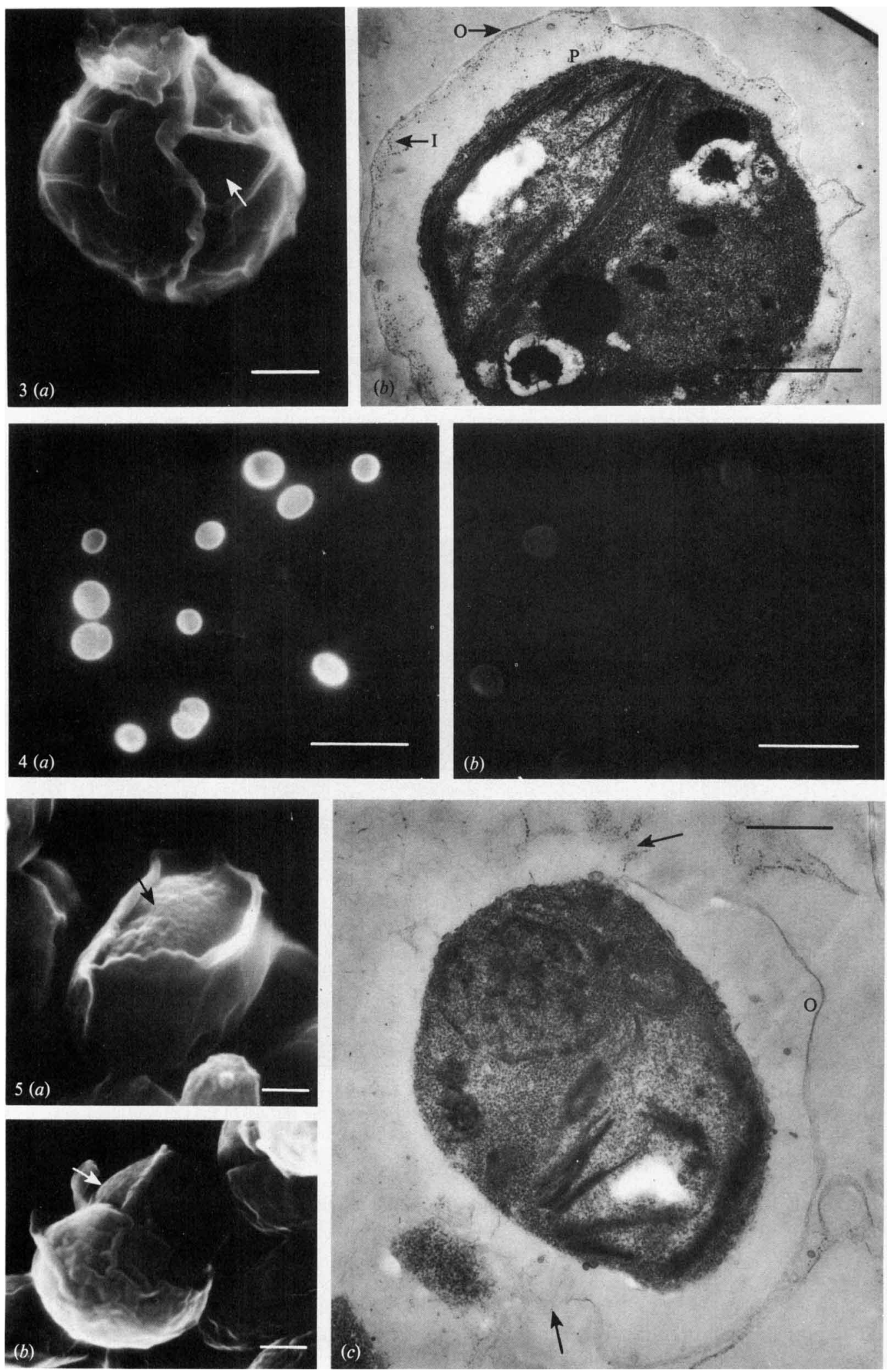

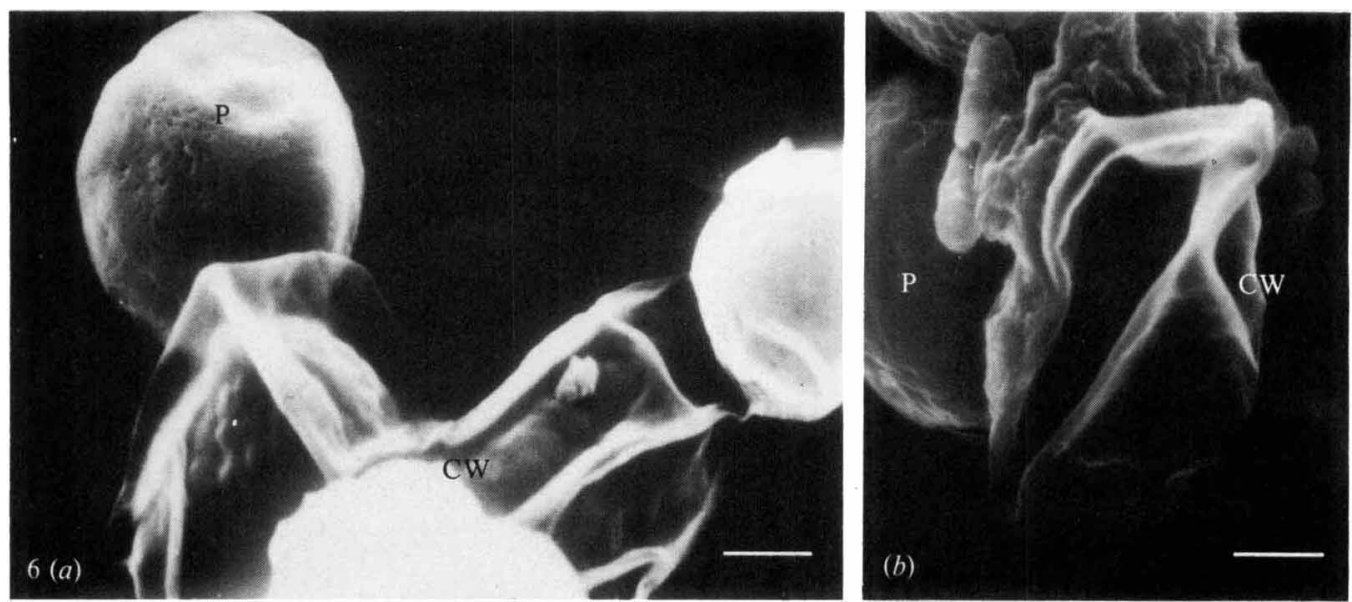

Fig. 6. Scanning electron micrographs showing the last stage of protoplast formation. (a) A protoplast (P) emerging from a degrading cell wall $(\mathrm{CW})$. $(b)$ The empty wall structure $(\mathrm{CW})$ remains beside the protoplast. The bar markers represent $1 \mu \mathrm{m}$.

In the former case, the cell wall 'dissolved', and in the latter case, the protoplasts extruded through breaks in the cell wall, probably through vegetative division scars. Our electron microscopic observations, however, revealed that the cell wall of $C$. ellipsoidea degraded from within: firstly, the inner microfibrillar component was digested, then the outer thin component gradually degraded. The surface of plasma membrane was exposed through the break on the cell wall at intermediate stages of the degradation, but whether the break occurred by a site-specific digestion at structures such as the division scar suggested by Berliner (1977) or the damage lines of Enteromorpha cell wall (McArthur \& Moss, 1977) could not be decided.

The sensitivity of the cell wall to the enzyme digestion might vary during some stages in the developmental cycle. We observed that autospores of $C$. ellipsoidea $\mathrm{C}-87$ were also degraded by the enzyme mixture; the cell wall of maturing autospores was completely degraded while the outer region of mother cell wall was comparably intact. This may indicate that the stability of the outer region is acquired at the latest stage of cell wall formation.

Although the chemical composition of the two layers of the cell wall of $C$. ellipsoidea C-87 has not been fully studied, the presence of pectin and $\beta$-linked polysaccharides such as cellulose was indicated by staining with Ruthenium red and Calcofluor white ST, respectively. Our preliminary treatments of the cells with cellulase only and pectinase only indicated that the inner microfibrillar layer was cellulase-sensitive and the outer layer was pectinasesensitive (Fig. 10). Since the inner layer was much more sensitive to enzmye digestion than the outer layer, the limiting factor of protoplast formation of Chlorella would be the outer rigid layer; in fact, Aach et al. (1978) reported that protoplasts of $C$. saccharophila could be easily obtained by cellulase digestion after the outermost layer of the cell wall had been scratched with sea sand.

Fig. 3. Electron micrographs showing cells of $C$. ellipsoidea at an intermediate stage of protoplast formation. (a) Scanning electron micrograph showing a cell incubated for $3 \mathrm{~h}$ in the protoplast induction medium. The cell surface is roughly folded. A small split has occurred at a fold point (arrow). (b) Thin section of a cell incubated for $3 \mathrm{~h}$. The outer region $(\mathrm{O})$ of cell wall is released from the plasma membrane (P). The inner region (I) is considerably degraded. The bar markers represent $1 \mu \mathrm{m}$.

Fig. 4. Cell walls stained with Calcofluor white ST. (a) Whole cells in the exponential growth phase: the cell walls are strongly stained and bright. $(b)$ Cells treated with the enzyme mixture for $3 \mathrm{~h}$ : fluorescence around the cells was very faint. The bar markers represent $10 \mu \mathrm{m}$.

Fig. 5. Electron micrographs showing cells of $C$. ellipsoidea in the process of the protoplast formation. $(a, b)$ Scanning electron micrographs of cells incubated for $5 \mathrm{~h}$. Most of the cells have large breaks in their cell wall. The surface of the plasma membrane is exposed through the breaks in the cell wall (arrows). (c) Thin section of a cell incubated for $5 \mathrm{~h}$. The outer region of cell wall $(\mathrm{O})$ is degraded at some sites (arrows). The bar markers represent $1 \mu \mathrm{m}$. 

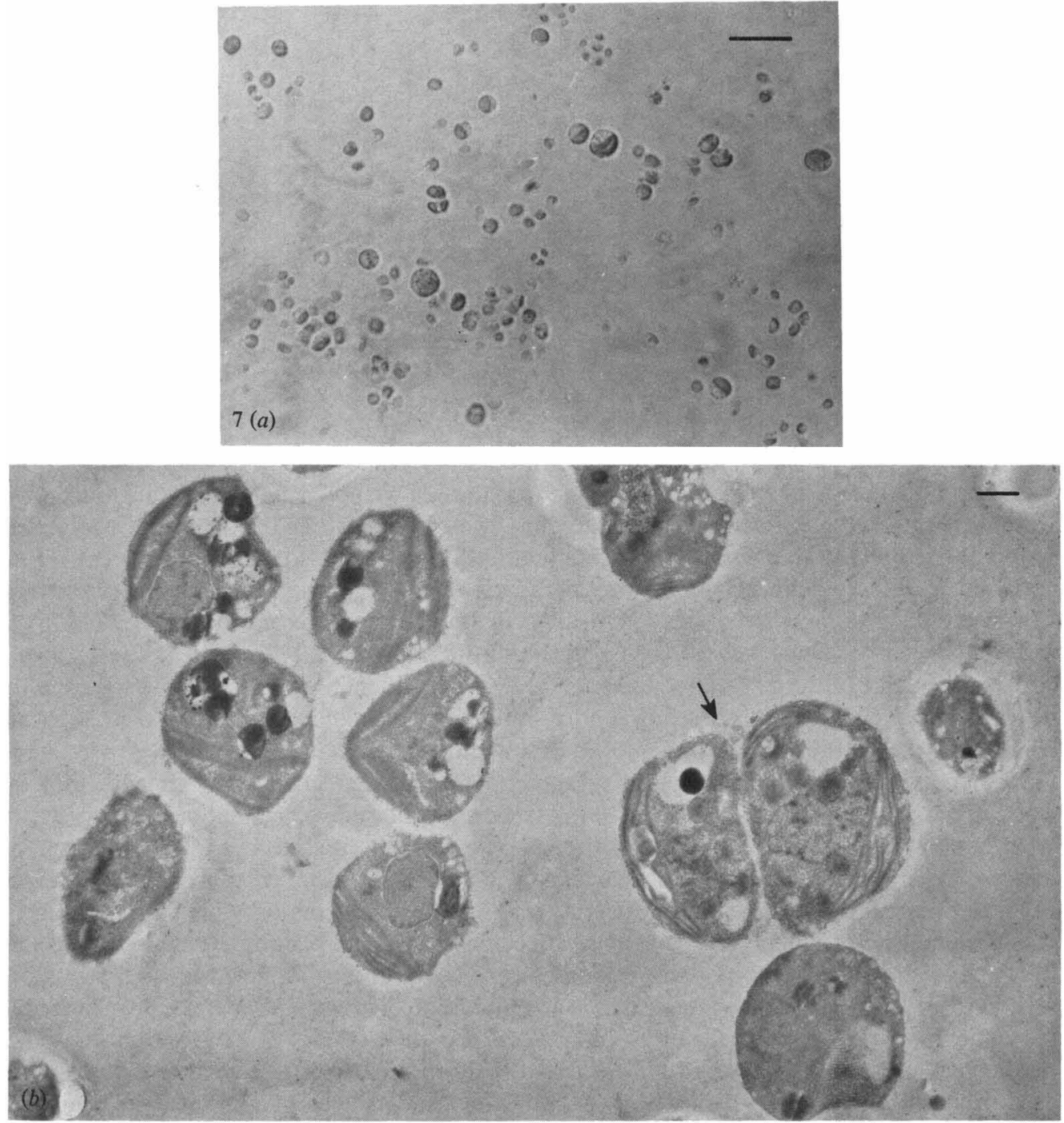

Fig. 7. Cells of $C$. ellipsoidea after the incubation for $8 \mathrm{~h}$. (a) Light micrograph: most cells have converted to spherical shape. There are a few large swollen cells. (b) Thin section of the cells. Most cells are without cell wall structures; some cells still retain the degrading outer layer of cell wall (arrow). The bar marker represents $10 \mu \mathrm{m}$ in $(a)$ and $1 \mu \mathrm{m}$ in $(b)$. 

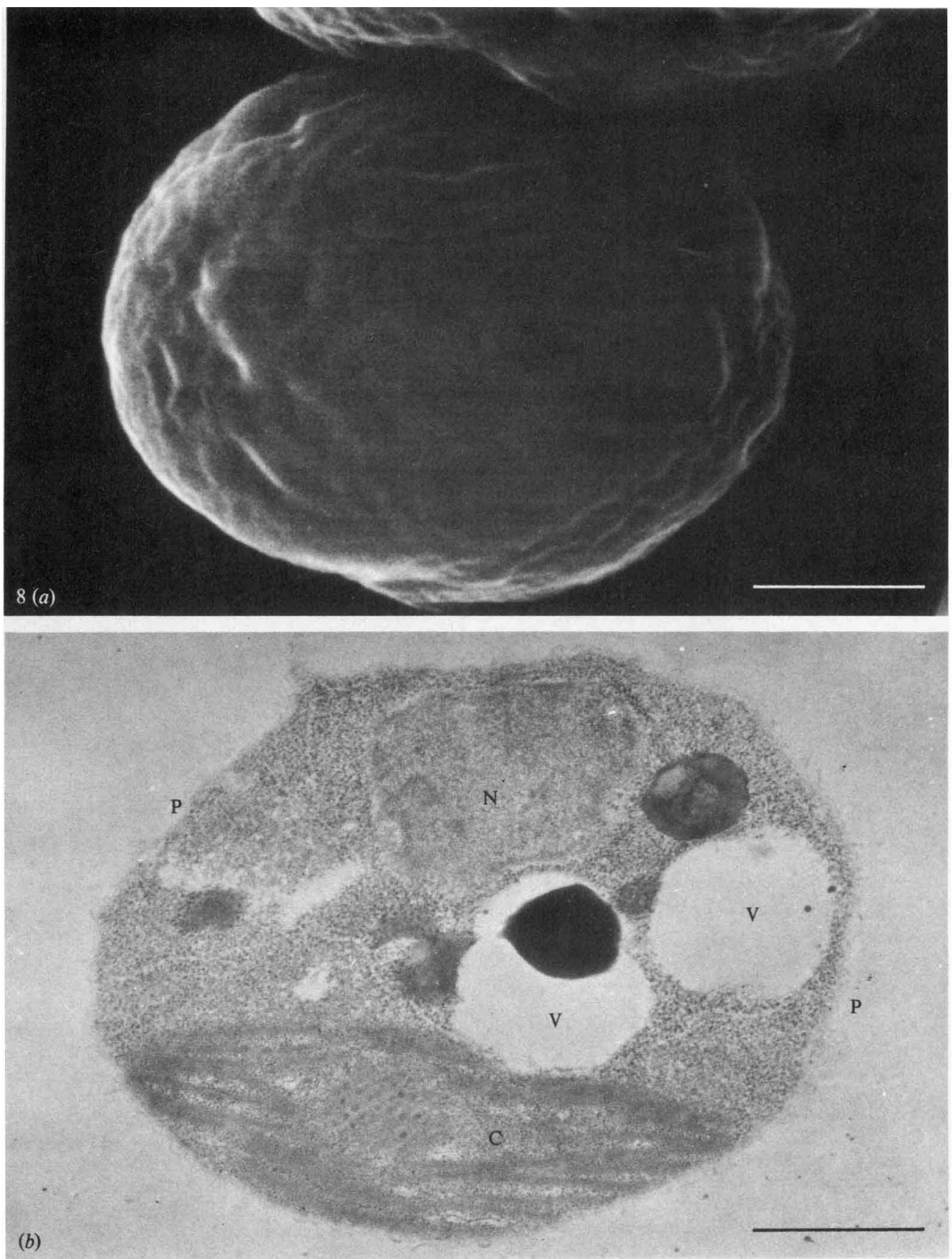

Fig. 8. Electron micrographs showing the protoplast of $C$. ellipsoidea after incubation for $8 \mathrm{~h}$. $(a)$ Scanning electron micrograph showing the finely rugose surface of the plasma membrane. (b) Thin section of the protoplast. The plasma membrane (P) is wavy. C, chloroplast; N, nucleus; V, vacuole. The bar markers represent $1 \mu \mathrm{m}$. 


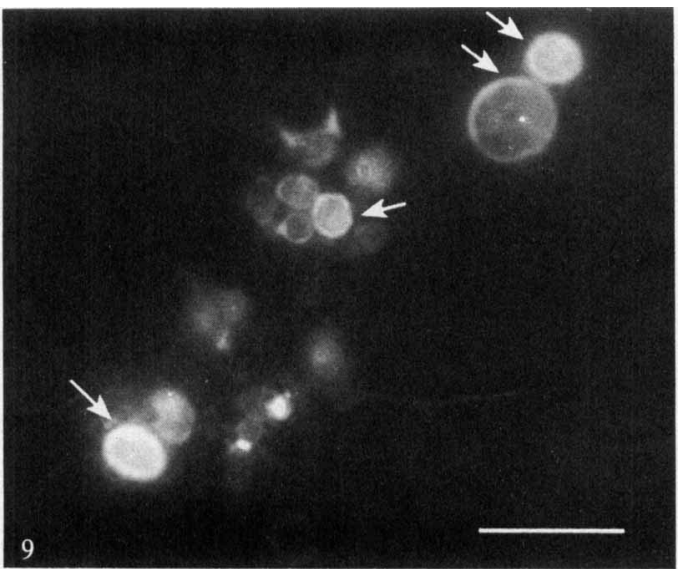

Fig. 9. Staining with Calcofluor white ST of protoplasts incubated in regeneration medium. After $3 \mathrm{~d}$ incubation at $25^{\circ} \mathrm{C}$ in the light $(3000 \mathrm{~lx})$, some cells in the protoplast aggregates were re-stained and brightened (arrows). The bar marker represents $10 \mu \mathrm{m}$.
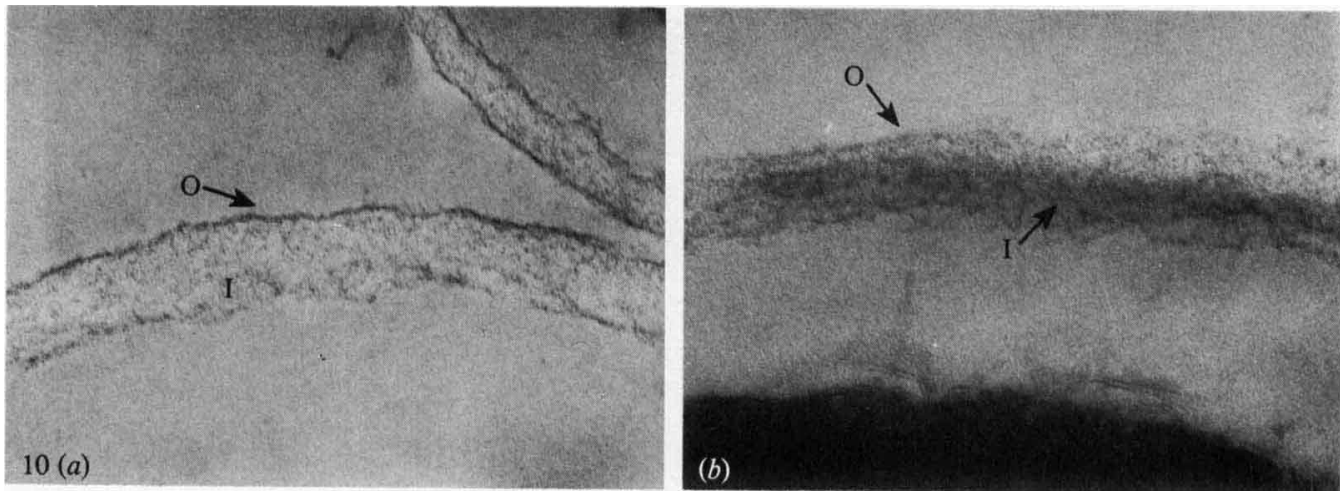

Fig. 10. Thin sections of the cell wall treated with $4 \%$ cellulase $(a)$ and $1 \%$ pectinase $(b)$. Incubation was carried out for $12 \mathrm{~h}$ at $25^{\circ} \mathrm{C}$. I, inner region of cell wall; $\mathrm{O}$, outer region of cell wall.

\section{REFERENCES}

Aach, H. G., Bartsch, S. \& Feyen, V. (1978). Studies on Chlorella protoplasts: demonstration of the protoplastic nature and the regeneration of the cell wall. Planta 139, 257-260.

Atkinson, A. W., JR., GunNing, B. E. S. \& John, P. C. L. (1972). Sporopollenin in the cell wall of Chlorella and other algae: ultrastructure, chemistry, and incorporation of ${ }^{14} \mathrm{C}$-acetate, studied in synchronous cultures. Planta 107, 1-32.

Berliner, M. D. (1977). Protoplast induction in Chlorella vulgaris. Plant Science Letters 9, 201204.

Braun, E. \& AACH, H. G. (1975). Enzymatic degradation of the cell wall of Chlorella. Planta 126, 181-185.

McArthur, D. M. \& Moss, B. L. (1977). Ultrastructure of cell wall in Enteromorpha intestinalis (L.) Link. British Phycological Journal 12, 1359-1368.

MAEDA, H. \& IsHIDA, N. (1967). Specificity of binding of hexapyranosyl polysaccharides with fluorescent brightener. Journal of Biochemistry 62, 276-278.

Millonig, G. (1963). A modified procedure for lead staining of thin sections. Journal of Biophysical and Biochemical Cytology 11, 736-739.

Millonig, G. \& MARINozzI, V. (1968). Fixation and embedding in electron microscopy. In Advances in Optical and Electron Microscopy, vol. II, pp. 251-341. Edited by R. Barer \& V. E. Cosslett. London: Academic Press.

Nagata, T. \& Takebe, I. (1970). Cell wall regeneration and cell division in isolated tobacco mesophyll protoplasts. Planta 92, 301-308.

SOEDER, C. J. (1963). Weitere zellmorphologische und physiologische Merkmale von Chlorella-Arten. In Studies on Microalgae and Photosynthetic Bacteria, pp. 21-34. Tokyo.

SoEder, C. J. (1964). Elektronenmikroskopische Untersuchungen an ungeteilten Zellen von Chlorella 
fusca Shihira et Krauss. Archiv für Mikrobiologie 47, 311-324.

Takeda, H. \& Hirokawa, T. (1978). Studies on the cell wall of Chlorella. I. Quantitative changes in cell wall polysaccharides during the cell cycle of Chlorella ellipsoidea. Plant and Cell Physiology 19, 591-598.
WatanABE, A. (1960). List of algal strains in collection at the Institute of Applied Microbiology, University of Tokyo. Journal of General and Applied Microbiology 6, 283-292.

YAmada, T. \& SAKaguchi, K. (1981). Protoplast induction in Chlorella species. Agricultural and Biological Chemistry 45, 1905-1909. 